\title{
Research on E7 country's investment environment evaluation based on principal component analysis
}

\author{
Deng Wenbo ${ }^{1,2}$ \\ ${ }^{1}$ Heyuan Polytechnic, Heyuan, Guangdong, 517000, China \\ ${ }^{2}$ School of Business, Macao University of Science and Technology, Macao \\ wenbodeng@163.com
}

Keywords: emerging market economics country, investment environment, assessment indicator system, Principal component analysis.

\begin{abstract}
The article uses PEST analysis model to comprehensively evaluate the investment environment of E7 emerging market countries. This paper selects 20 relative indicators of political, economic, social and technological environment. Using panel data from 2006 to 2015, the principal component analysis method is used to extract the principal components reflecting the level of investment environment, and the seven investment environments are comprehensively scored. The results show that the investment environment of Russia and Turkey is the best, that of China, Mexico and Brazil is better, and that of Indonesia and India is relatively poor.
\end{abstract}

\section{Introduction}

Price Waterhouse Coopers' report says that the main driving force for future world economic growth will come from emerging market countries. The seven emerging market countries (E7) of Brazil, Russia, India, China, Indonesia, Mexico and Turkey will grow twice as fast as the Seven industrialized countries (G7) in the next 30 years, attracting a lot of investment. And this has attracted the attention of many investors. The evaluation of the investment environment is the basis of making transnational investment decisions. For this reason, experts and scholars at home and abroad have done a lot of research on the investment environment. Litvak and Banting used "cold and hot method" to evaluate the investment environment. And Yang Haien used AHP method to evaluate the investment environment of six countries such as the United States. Meanwhile Liu Erhu, Fang Yin and Chen Junhua used entropy method to measure the investment environment of the eight Gulf countries. For the selection of evaluation indicators, most of the literature evaluates the investment environment from the aspects of politics and policy, economic environment, natural environment, social environment indicators, science and technology environment. However, existing studies tend to choose aggregate indicators and cross-sectional data to evaluate the investment environment of countries.

Because of the great disparity of population and region between countries, the use of aggregate indicators is often not comparable. For example, in ASEAN countries, Indonesia's GDP is far greater than Singapore's, and its per capita GDP is less than one tenth of Singapore's. At the same time, transnational investment is often a long-term decision, and short-term data indicators are difficult to carry out objective evaluation. Based on the PEST analysis model, this paper selects representative relative indicators, collects panel data from 2006 to 2015, and uses principal component analysis to evaluate the investment environment of E7 countries.

\section{Construction of evaluation index system for investment environment}

The most important thing is to select suitable index system for evaluating the investment environment of a country. According to the existing literature, most experts and scholars choose the evaluation index from some aspects, such as policy, economy, society, technology, basic conditions and natural conditions. Because most of the natural conditions are difficult to quantify, and for different types of investment projects, the requirements of natural conditions are not the same, and 
this paper aims to evaluate the overall investment environment, so there is no selection of natural conditions indicators. Therefore, according to the PEST analysis model, this paper selects the relative indicators of political and policy environment, economic environment, social environment and technological environment to evaluate the national investment environment, and constructs the first-class indicators, second-class indicators and third-class indicators as shown in Table 1.

Table 1 evaluation index of investment environment

\begin{tabular}{|c|c|c|c|c|}
\hline $\begin{array}{l}\text { First level } \\
\text { index }\end{array}$ & $\begin{array}{l}\text { Second level } \\
\text { index }\end{array}$ & Third level index & & unit \\
\hline \multirow[t]{3}{*}{$\begin{array}{l}\text { Political } \\
\text { environment }\end{array}$} & $\begin{array}{l}\text { Stability of } \\
\text { the regime }\end{array}$ & Ratio of armed force to labor force & $\mathrm{X} 1$ & $\%$ \\
\hline & \multirow{2}{*}{$\begin{array}{l}\text { Policy } \\
\text { environment }\end{array}$} & Government consumption ratio GDP & $\mathrm{X} 2$ & $\%$ \\
\hline & & $\begin{array}{l}\text { Domestic credit provided by financial } \\
\text { sector is GDP }\end{array}$ & X3 & $\%$ \\
\hline \multirow[t]{10}{*}{$\begin{array}{l}\text { economic } \\
\text { environment }\end{array}$} & \multirow[t]{2}{*}{ Growth rate } & $\begin{array}{l}\text { Total fixed capital formation ratio } \\
\text { GDP }\end{array}$ & $\mathrm{X} 4$ & $\%$ \\
\hline & & GDP growth rate & $\mathrm{X} 5$ & $\%$ \\
\hline & \multirow[t]{2}{*}{$\begin{array}{l}\text { economic } \\
\text { structure }\end{array}$} & $\begin{array}{l}\text { Value added ratio of service industry } \\
\text { is GDP }\end{array}$ & X6 & $\%$ \\
\hline & & Industrial added value ratio GDP & $\mathrm{X7}$ & $\%$ \\
\hline & \multirow{2}{*}{$\begin{array}{l}\text { Economic } \\
\text { level }\end{array}$} & Per capita GDP & $\mathrm{X} 8$ & US dollar / person \\
\hline & & per capita income & X9 & US dollar / person \\
\hline & \multirow{2}{*}{$\begin{array}{l}\text { Consumption } \\
\text { capacity }\end{array}$} & Final consumption ratio GDP & $\mathrm{X} 10$ & $\%$ \\
\hline & & Domestic expenditure ratio GDP & $\mathrm{X} 11$ & $\%$ \\
\hline & \multirow{2}{*}{$\begin{array}{l}\text { Foreign } \\
\text { economy }\end{array}$} & Goods service import ratio GDP & $\mathrm{X} 12$ & $\%$ \\
\hline & & Goods service export ratio GDP & $\mathrm{X} 13$ & $\%$ \\
\hline \multirow{5}{*}{$\begin{array}{l}\text { social } \\
\text { environment }\end{array}$} & \multirow{2}{*}{$\begin{array}{l}\text { social } \\
\text { foundation }\end{array}$} & Electricity consumption ratio & $\mathrm{X} 14$ & $\%$ \\
\hline & & $\begin{array}{l}\text { The proportion of people using basic } \\
\text { drinking water }\end{array}$ & $\mathrm{X} 15$ & $\%$ \\
\hline & $\begin{array}{l}\text { population } \\
\text { quality }\end{array}$ & Education expenditure is GNI & $\mathrm{X} 16$ & $\%$ \\
\hline & \multirow{2}{*}{$\begin{array}{l}\text { Healthy } \\
\text { employment }\end{array}$} & Per capita health expenditure & $\mathrm{X} 17$ & US dollar / person \\
\hline & & 15-64 year old employment rate & $\mathrm{X} 18$ & $\%$ \\
\hline \multirow{2}{*}{$\begin{array}{l}\text { Science and } \\
\text { technology } \\
\text { environment }\end{array}$} & $\begin{array}{l}\text { Technological } \\
\text { innovation }\end{array}$ & $\begin{array}{l}\text { Number of patent applications per } \\
\text { million }\end{array}$ & $\mathrm{X} 19$ & $\begin{array}{l}\text { One / ten thousand } \\
\text { people }\end{array}$ \\
\hline & $\begin{array}{l}\text { scientific } \\
\text { research }\end{array}$ & $\begin{array}{l}\text { Number of papers published by ten } \\
\text { thousand people }\end{array}$ & $\mathrm{X} 20$ & $\begin{array}{l}\text { An article / ten } \\
\text { thousand people }\end{array}$ \\
\hline
\end{tabular}

\section{Data sources and analysis process}

\section{1 data sources}

In order to ensure the authenticity and reliability of the data, all the indicators in this paper are derived from the 2006-2015 World Bank statistics.

\subsection{Principal component analysis}

Principal Component Analysis (PCA) is a multivariate statistical analysis method which transforms multiple indexes into a few principal components by linear transformation with the idea of data dimensionality reduction. The principal component index extracted by this method should reflect the original information as much as possible. Generally, more than $85 \%$ of the original variable information should be retained. The concrete calculation model of principal component analysis is:

$\left\{\begin{array}{c}\mathrm{F}_{1}=\mathrm{u}_{11} \mathrm{x}_{1}+\mathrm{u}_{12} \mathrm{x}_{2}+\ldots+\mathrm{u}_{1 \mathrm{j}} \mathrm{x}_{\mathrm{j}} \\ \mathrm{F}_{2}=\mathrm{u}_{21} \mathrm{x}_{1}+\mathrm{u}_{22} \mathrm{x}_{2}+\ldots+\mathrm{u}_{2 \mathrm{j}} \mathrm{x}_{\mathrm{j}} \\ \ldots \\ \mathrm{F}_{\mathrm{p}}=\mathrm{u}_{\mathrm{p} 1} \mathrm{x}_{1}+\mathrm{u}_{\mathrm{p} 2} \mathrm{x}_{2}+\ldots+\mathrm{u}_{\mathrm{pj}} \mathrm{x}_{\mathrm{j}}\end{array}\right.$ 
The original data matrix of the model is: $X=\left(x_{i j}\right) m * n, i=1,2, \ldots m ; j=1,2, \ldots n$. The I principal component of $\mathrm{X}$ is: $\mathrm{F}_{\mathrm{i}}=\mathrm{a}_{\mathrm{i}} \mathrm{X}$.

Among them, $\mathrm{F}_{1}, \mathrm{~F}_{2} \ldots \mathrm{F}_{\mathrm{P}}$ is a $\mathrm{P}$ principal component. Based on the data of 13 indexes from 2006 to 2015 in Heyuan City, this paper calculates the scores of principal component and comprehensive component in each year.

\subsection{E7 National investment environment evaluation process}

SPSS20.0 is used to analyze the data of Heyuan industrial economic growth evaluation index for 2006-2015 years. Because the dimensions of each index are different, SPSS20.0 first standardizes the original indexes and extracts five principal components whose initial eigenvalues are greater than 1, as shown in Table 2.

Table 2 total variance explained by principal components

\begin{tabular}{lrrrrrr}
\hline \multirow{2}{*}{ component } & \multicolumn{3}{c}{ Initial eigenvalue } & \multicolumn{2}{c}{ Extracting sum of squares } \\
\cline { 2 - 7 } & Total & variance\% & Cumulative\% & Total & variance\% & $\begin{array}{c}\text { Cumulativ } \\
\mathrm{e} \%\end{array}$ \\
\hline 1 & 8.557 & 42.785 & 42.785 & 8.557 & 42.785 & 42.785 \\
\hline 2 & 4.155 & 20.775 & 63.560 & 4.155 & 20.775 & 63.560 \\
\hline 3 & 2.298 & 11.491 & 75.050 & 2.298 & 11.491 & 75.050 \\
\hline 4 & 1.984 & 9.922 & 84.973 & 1.984 & 9.922 & 84.973 \\
\hline 5 & 1.121 & 5.604 & 90.577 & 1.121 & 5.604 & 90.577 \\
\hline
\end{tabular}

The five principal components extracted in Table 2 accumulatively explain $90.577 \%$ of the original data, so it is appropriate to take five principal components. Five principal components, $\mathrm{F}_{1}$, $F_{2}, F_{3}, F_{4}$ and $F_{5}$, are used to evaluate the investment environment of E7 emerging market countries, representing the original 20 original indicators.

Table 3 component matrix a

\begin{tabular}{|c|c|c|c|c|c|}
\hline \multirow[t]{2}{*}{ evaluating indicator } & \multicolumn{5}{|c|}{ Components } \\
\hline & $\mathrm{F}_{1}$ & $\mathrm{~F}_{2}$ & $\mathrm{~F}_{3}$ & $\mathrm{~F}_{4}$ & $\mathrm{~F}_{5}$ \\
\hline Armed forces are $\mathrm{X}_{1}$ & .575 & -.060 & .483 & .387 & -.514 \\
\hline Government consumption is GDP $\mathrm{X}_{2}$ & .767 & .406 & -.273 & -.029 & -.277 \\
\hline $\begin{array}{l}\text { Domestic credit provided by the financial } \\
\text { sector is GDP } \mathrm{X}_{3}\end{array}$ & -.192 & .597 & -.509 & .448 & .301 \\
\hline $\begin{array}{l}\text { The total amount of fixed capital formation is } \\
\text { GDP } \mathrm{X}_{4}\end{array}$ & -.755 & .389 & -.042 & .461 & .148 \\
\hline GDP growth rate $X_{5}$ & -.598 & .186 & -.027 & .360 & -.091 \\
\hline The added value of service industry is GDP $\mathrm{X}_{6}$ & .893 & -.104 & -.023 & -.023 & .350 \\
\hline Industrial added value is GDP $\mathrm{X}_{7}$ & -.782 & .392 & .269 & -.205 & .138 \\
\hline Per capita GDP $\mathrm{X}_{8}$ & .902 & .229 & .208 & .067 & .102 \\
\hline Per capita income $\mathrm{X}_{9}$ & .825 & .266 & .403 & .056 & -.003 \\
\hline Final consumption is GDP $\mathrm{X}_{10}$ & .716 & -.649 & -.068 & -.166 & .018 \\
\hline Domestic expenditure is GDP $\mathrm{X}_{11}$ & .039 & -.713 & -.214 & .540 & .337 \\
\hline Import of goods services is GDP $\mathrm{X}_{12}$ & -.354 & -.391 & .703 & .167 & .407 \\
\hline Exports of goods are more than GDP $\mathrm{X}_{13}$ & -.366 & .158 & .829 & -.243 & .136 \\
\hline Electricity consumption population $\mathrm{X}_{14}$ & .568 & .537 & .265 & -.134 & .135 \\
\hline $\begin{array}{l}\text { The proportion of people using basic drinking } \\
\text { water is } \mathrm{X}_{15}\end{array}$ & .897 & .227 & .149 & .218 & .180 \\
\hline Education expenditure is GNI $\mathrm{X}_{16}$ & .744 & -.397 & -.232 & -.321 & .261 \\
\hline
\end{tabular}




\begin{tabular}{lccccr}
\hline Per capita health expenditure $\mathrm{X}_{17}$ & .939 & .163 & -.123 & -.055 & .143 \\
\hline 15-64 years old employment rate $\mathrm{X}_{18}$ & -.126 & .759 & -.200 & -.580 & .052 \\
\hline The number of patents per 10000 people is $\mathrm{X}_{19}$ & .091 & .872 & -.005 & .053 & .224 \\
\hline Number of journal articles per $10000 \mathrm{X}_{20}$ & .639 & .436 & .132 & .570 & -.130 \\
\hline
\end{tabular}

As can be seen from table 3, first of all, F1 is in the government consumption ratio, fixed capital formation ratio, GDP growth rate, service industry value-added ratio, industrial value-added ratio, per capita GDP, per capita income, final consumption ratio, electricity consumption, the proportion of people using basic drinking water, the proportion of people using basic drinking water, and education expenditure. Compared with GNI, per capita health expenditure and the number of papers per 10,000 journals, it reflects the basic situation of domestic policy, economy, society and technology. Secondly, the domestic credit ratio GDP, the final consumption ratio GDP, the domestic expenditure ratio GDP, the employment rate of 15-64 years old and the number of patents per 10,000 people provided by F2 in the financial sector have a higher load, reflecting the financing, consumption, employment and technological innovation. Thirdly, F3 has a higher load on imports of goods and services than GDP and exports of goods and services than GDP, reflecting the international trade situation. Fourth, F4 has a higher load in the number of journal articles per 10000 people, reflecting the scientific research situation. Fifth, the load of F5 in the armed forces reflects the stability of the regime. The above five principal components can basically reflect the information of all indicators. The component score coefficient matrix of Table 4 is further calculated.

Table 4 component score coefficient matrix

\begin{tabular}{|c|c|c|c|c|c|}
\hline \multirow[t]{2}{*}{ evaluating indicator } & \multicolumn{5}{|c|}{ Components } \\
\hline & 1 & 2 & 3 & 4 & 5 \\
\hline Armed forces are $X_{1}$ & .067 & -.015 & .210 & .195 & -.459 \\
\hline Government consumption is GDP $\mathrm{X}_{2}$ & .090 & .098 & -.119 & -.015 & -.247 \\
\hline $\begin{array}{l}\text { Domestic credit provided by the financial } \\
\text { sector is GDP } \mathrm{X}_{3}\end{array}$ & -.022 & .144 & -.221 & .226 & .269 \\
\hline $\begin{array}{l}\text { The total amount of fixed capital } \\
\text { formation is GDP } \mathrm{X}_{4}\end{array}$ & -.088 & .094 & -.018 & .232 & .132 \\
\hline GDP growth rate $X_{5}$ & -.070 & .045 & -.012 & .181 & -.081 \\
\hline $\begin{array}{l}\text { The added value of service industry is } \\
\text { GDP } \mathrm{X}_{6}\end{array}$ & .104 & -.025 & -.010 & -.012 & .313 \\
\hline Industrial added value is GDP $\mathrm{X}_{7}$ & -.091 & .094 & .117 & -.103 & .124 \\
\hline Per capita GDP $\mathrm{X}_{8}$ & .105 & .055 & .090 & .034 & .091 \\
\hline Per capita income $\mathrm{X}_{9}$ & .096 & .064 & .175 & .028 & -.003 \\
\hline Final consumption is GDP $\mathrm{X}_{10}$ & .084 & -.156 & -.029 & -.084 & .016 \\
\hline Domestic expenditure is GDP $\mathrm{X}_{11}$ & .005 & -.172 & -.093 & .272 & .301 \\
\hline Import of goods services is GDP $\mathrm{X}_{12}$ & -.041 & -.094 & .306 & .084 & .363 \\
\hline Exports of goods are more than GDP $\mathrm{X}_{13}$ & -.043 & .038 & .361 & -.123 & .121 \\
\hline Electricity consumption population $\mathrm{X}_{14}$ & .066 & .129 & .115 & -.067 & .120 \\
\hline $\begin{array}{l}\text { The proportion of people using basic } \\
\text { drinking water is } \mathrm{X}_{15}\end{array}$ & .105 & .055 & .065 & .110 & .160 \\
\hline Education expenditure is GNI $\mathrm{X}_{16}$ & .087 & -.096 & -.101 & -.162 & .233 \\
\hline Per capita health expenditure $\mathrm{X}_{17}$ & .110 & .039 & -.054 & -.028 & .127 \\
\hline $15-64$ years old employment rate $X_{18}$ & -.015 & .183 & -.087 & -.292 & .046 \\
\hline
\end{tabular}




\begin{tabular}{llllll}
\hline $\begin{array}{l}\text { The number of patents per } 10000 \text { people } \\
\text { is } \mathrm{X}_{19}\end{array}$ & .011 & .210 & -.002 & .027 & .200 \\
\hline Number of journal articles per $10000 \mathrm{X}_{20}$ & .075 & .105 & .057 & .287 & -.116 \\
\hline
\end{tabular}

According to table 4, the F1 principal component score is calculated as follows:

$\mathrm{F}_{1}=0.067 \mathrm{X}_{1}+0.090 \mathrm{X}_{2}-0.022 \mathrm{X}_{3}-0.088 \mathrm{X}_{4}-0.070 \mathrm{X}_{5}+0.104 \mathrm{X}_{6}-0.091 \mathrm{X}_{7}+0.105 \mathrm{X}_{8}+0.096 \mathrm{X}_{9}+0.084 \mathrm{X}_{10}$ $+0.005 \mathrm{X}_{11}-0.041 \mathrm{X}_{12}-0.043 \mathrm{X}_{13}+0.066 \mathrm{X}_{14}+0.105 \mathrm{X}_{15}+0.087 \mathrm{X}_{16}+0.110 \mathrm{X}_{17}-0.011 \mathrm{X}_{18}+0.011 \mathrm{X}_{19}+0.0$ $75 \mathrm{X}_{20}$

The principles of $F_{2}, F_{3}, F_{4}$ and $F_{5}$ scoring formulas are the same as those of $F_{1}$, and they are not listed here. Combined with the relative variance contribution rate of table 2, the comprehensive score formula of investment environment assessment for each country is as follows:

$\mathrm{F}=0.42785 \mathrm{~F}_{1}+0.20775 \mathrm{~F}_{2}+0.11491 \mathrm{~F}_{3}+0.09922 \mathrm{~F}_{4}+0.05604 \mathrm{~F}_{5}$

We can find out the total investment environment of E7 countries in 2006 -2015, as shown in Table 5.

Table 5 E7 national investment environment 2006 -2015 comprehensive evaluation score

\begin{tabular}{|c|c|c|c|c|c|c|c|c|c|c|c|}
\hline Country & $\begin{array}{l}\text { Particular } \\
\text { year }\end{array}$ & 2006 & 2007 & 2008 & 2009 & 2010 & 2011 & 2012 & 2013 & 2014 & 2015 \\
\hline \multirow[t]{2}{*}{ Brazil } & Score & -0.03 & 0.05 & 0.13 & 0.16 & 0.25 & 0.35 & 0.37 & 0.41 & 0.44 & 0.36 \\
\hline & ranking & 4 & 4 & 3 & 3 & 3 & 3 & 3 & 3 & 3 & 4 \\
\hline \multirow[t]{2}{*}{ Russia } & Score & 0.19 & 0.29 & 0.44 & 0.41 & 0.45 & 0.57 & 0.64 & 0.70 & 0.66 & 0.61 \\
\hline & ranking & 2 & 2 & 1 & 2 & 1 & 1 & 1 & 1 & 1 & 1 \\
\hline \multirow[t]{2}{*}{ India } & Score & -0.95 & -0.92 & -0.82 & -0.80 & -0.76 & -0.77 & -0.65 & -0.65 & -0.63 & -0.60 \\
\hline & ranking & 7 & 7 & 7 & 7 & 7 & 7 & 7 & 7 & 7 & 7 \\
\hline \multirow[t]{2}{*}{ China } & Score & -0.34 & -0.29 & -0.22 & -0.16 & -0.07 & 0.05 & 0.15 & 0.27 & 0.37 & 0.49 \\
\hline & ranking & 5 & 5 & 5 & 5 & 5 & 5 & 5 & 4 & 4 & 3 \\
\hline \multirow[t]{2}{*}{ Indonesia } & Score & -0.82 & -0.80 & -0.76 & -0.77 & -0.69 & -0.63 & -0.58 & -0.55 & -0.52 & -0.50 \\
\hline & ranking & 6 & 6 & 6 & 6 & 6 & 6 & 6 & 6 & 6 & 6 \\
\hline \multirow[t]{2}{*}{ Mexico } & Score & 0.02 & 0.06 & 0.11 & 0.09 & 0.15 & 0.20 & 0.24 & 0.27 & 0.29 & 0.30 \\
\hline & ranking & 3 & 3 & 4 & 4 & 4 & 4 & 4 & 5 & 5 & 5 \\
\hline \multirow[t]{2}{*}{ Turkey } & Score & 0.23 & 0.34 & 0.42 & 0.42 & 0.45 & 0.50 & 0.55 & 0.60 & 0.62 & 0.58 \\
\hline & ranking & 1 & 1 & 2 & 1 & 2 & 2 & 2 & 2 & 2 & 2 \\
\hline
\end{tabular}

\section{Summary}

The empirical results show that the investment environment assessment scores of E7 emerging market countries are on the rise from 2006 to 2015. First, Russia and Turkey have consistently ranked the top 2 in terms of investment environment, with the best investment environment. Secondly, China, Mexico and Brazil have been ranked 3-5, indicating that the investment environment of these three countries is better. Although Mexico's ranking is declining among the three countries, its scoring level has been relatively stable, and China's ranking has improved greatly since 2013. Finally, Indonesia and India were in the last two places, with negative scores, suggesting that the investment climate needs further improvement. 


\section{References}

[1] Litval I A, Banting P M. A Conceptual Framework for International Business Arrangements [C]. American Marketing Association, pp: 460-467,1968

[2] Yang Hai-en. Evaluation About Overseas Investment Environment of Chinese Petroleum Enterprises Based on AHP[J]. Economic Problem,pp81-84,2013

[3] Fang Yin,Chen Jun-hua,Dai Huan-huan. Evaluation on investment of the Gulf Area under "The Belt and Road” vision[J]. World Regional Studies, vol.27(2)pp.36-44,2018

[4] Liu Er-hu, Chen Ying. Research on investment environmental comparison in Central Asia under the background of The Silk Road Economic Belt[J]. World Regional Studies, vol.27(4)pp.100-107,2018

[5] Quan Heng, Zhang Peng-fei. The Analysis of the Belt and Construction and Business the Investment Environment in Asia[J]. Journal of Shanghai University of Finance and Economics, vol.19(1)pp88-102,2017

[6] Zhao Zhong-jun, Jiang Dong-mei. Research on Evaluation of Urban Human Capital Competitiveness in Human Based on Principal Component Analysis[J]. Journal of Xiangtan University(Philosophy and Social Science), vol.41(1)pp102-105,2017 